\title{
Biosynthesis of Sespendole
}

\author{
Ryuji Uchida, Hiroshi Tomoda, Satoshi Ōmura
}

Received: February 22, 2006 / Accepted: May 13, 2006

(C) Japan Antibiotics Research Association

\begin{abstract}
Sespendole is the first reported fungal metabolite having an indolosesquiterpene core structure. The biosynthesis of sespendole was studied here by feeding experiments with $\left[{ }^{13} \mathrm{C}\right]$ acetate, $\left[{ }^{15} \mathrm{~N}\right]$ anthranilic acid and $\left[{ }^{13} \mathrm{C}\right]$ tryptophan. The data suggested that a farnesyl residue derived from the mevalonate pathway and an anthranilatederived indole-3-glycerol phosphate residue are condensed, and then cyclization occurs along with rearrangement to form the indolosesquiterpene core.
\end{abstract}

Keywords sespendole, biosynthesis, fungal metabolite, indolosesquiterpene

\section{Introduction}

Sespendole (1), discovered as an inhibitor of lipid droplet synthesis in macrophages [1], is the first reported fungal metabolite having the indolosesquiterpene core structure (Fig. 1) $[2,3]$. A number of fungal metabolites having the

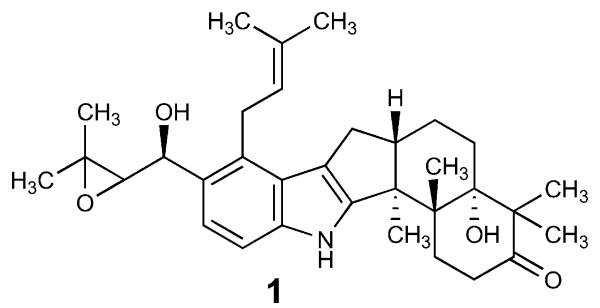

Fig. 1 Structure of sespendole (1).

H. Tomoda (Corresponding author), R. Uchida: School of Pharmaceutical Sciences, Kitasato University, 5-9-1 Shirokane, Minato-ku, Tokyo 108-8641, Japan,

E-mail: tomodah@pharm.kitasato-u.ac.jp

S. Ōmura: Kitasato Institute for Life Sciences, Kitasato University and The Kitasato Institute, 5-9-1 Shirokane, Minatoku, Tokyo 108-8641, Japan indoloditerpene core structure and their biosynthesis have been reported [4 6]. Fundamentally, an indole moiety and a diterpene moiety derived from geranylgeranyl pyrophosphate through the mevalonate pathway are condensed and cyclized to form the core structure. In this study, the biosynthesis of $\mathbf{1}$ was investigated by feeding experiments using $\left[{ }^{13} \mathrm{C}\right]$ acetate, $\left[{ }^{13} \mathrm{C}\right]$ tryptophan and $\left[{ }^{15} \mathrm{~N}\right]$ anthranilic acid to confirm the biosynthetic origin of the indolosesquiterpene compound.

\section{Materials and Methods}

\section{Spectroscopic Measurements}

The patterns and rates of incorporation of ${ }^{13} \mathrm{C}$-labeled $\mathbf{1}$ were determined using ${ }^{13} \mathrm{C}$ NMR spectra obtained using a JEOL EX-270 (270 MHz) spectrometer and the ${ }^{13} \mathrm{C}-{ }^{15} \mathrm{~N}$ coupling of ${ }^{15} \mathrm{~N}$-labeled 1 was determined from the ${ }^{13} \mathrm{C}$ NMR spectra obtained using a Varian Inova 600 $(600 \mathrm{MHz})$.

\section{Materials}

Isotope precursors were purchased as follows: sodium $\left[1-{ }^{13} \mathrm{C}\right]$ acetate, sodium $\left[2-{ }^{13} \mathrm{C}\right]$ acetate and sodium $[1,2-$ $\left.{ }^{13} \mathrm{C}\right]$ acetate from SIGMA, and $\left[2-{ }^{13} \mathrm{C}\right]$ tryptophan and $\left[{ }^{15} \mathrm{~N}\right]$ anthranilic acid from Cambridge Isotope Laboratories. Sespendole was isolated from the culture broth of fungal strain Pseudobotrytis terestris FKA-25 [3].

\section{Sespendole Production}

A stock culture of strain $P$. terrestris FKA-25 was grown on slants adjusted to $\mathrm{pH} \quad 6.0$ and containing $0.1 \%$ glycerol, $0.02 \%$ yeast extract (Oriental Yeast Co.), $0.02 \%$ $\mathrm{MgSO}_{4} \cdot 7 \mathrm{H}_{2} \mathrm{O}, 0.08 \% \mathrm{KH}_{2} \mathrm{PO}_{4}, 0.08 \% \mathrm{~K}_{2} \mathrm{HPO}_{4}, 0.02 \%$ $\mathrm{KCl}, 0.02 \% \mathrm{NaNO}_{3}$ and $1.0 \%$ agar. The slants were incubated at $27^{\circ} \mathrm{C}$ and stored in tubes sealed with screw caps at $27^{\circ} \mathrm{C}$. Prior to production of $\mathbf{1}$, P. terrestris FKA-25 
Table 1 Summary of ${ }^{13} \mathrm{C}$ enrichment and coupling constants resulting from incorporation of various $\left[{ }^{13} \mathrm{C}\right]$ acetate into $1\left(\mathrm{CD}_{3} \mathrm{OD}\right)$

\begin{tabular}{|c|c|c|c|c|c|c|c|}
\hline \multirow{2}{*}{ No. } & \multirow{2}{*}{$\begin{array}{c}\text { Chemical } \\
\text { shift } \\
\text { (ppm) }\end{array}$} & \multicolumn{2}{|c|}{$\left[2-{ }^{13} \mathrm{C}\right]$ Acetate } & \multicolumn{2}{|c|}{$\left[1-{ }^{13} \mathrm{C}\right]$ Acetate } & \multicolumn{2}{|c|}{$\left[1,2-{ }^{13} C\right]$ Acetate ${ }^{a}$} \\
\hline & & $\begin{array}{c}\text { Intensity } \\
\text { ratio }^{\mathrm{a}}\end{array}$ & $\begin{array}{c}J_{13 \mathrm{C}-13 \mathrm{C}} \\
(\mathrm{Hz})\end{array}$ & $\begin{array}{c}\text { Intensity } \\
\text { ratio }^{a}\end{array}$ & $\begin{array}{c}J_{13 \mathrm{C}-13 \mathrm{C}} \\
(\mathrm{Hz})\end{array}$ & $\begin{array}{c}\text { Intensity } \\
\text { ratio }^{a}\end{array}$ & $\begin{array}{c}J_{13 \mathrm{C}-13 \mathrm{C}} \\
(\mathrm{Hz})\end{array}$ \\
\hline 2 & 154.6 & 1.0 & & 1.0 & & 1.0 & - \\
\hline 3 & 53.9 & 1.0 & & 2.0 & $(40.5)^{b}$ & 2.2 & 35.4 \\
\hline 4 & 44.5 & 0.9 & & 1.6 & $(40.5)^{b}$ & 1.9 & 35.0 \\
\hline 5 & 29.6 & 2.5 & & 1.0 & & 2.2 & $(35.2)^{b}$ \\
\hline 6 & 35.6 & 1.0 & & 2.0 & & 2.3 & 37.8 \\
\hline 7 & 221.0 & 2.5 & & 0.9 & & 2.5 & 37.9 \\
\hline 8 & 56.2 & 1.0 & & 1.9 & & 2.0 & 34.1 \\
\hline 9 & 81.8 & 2.5 & & 0.9 & & 2.1 & 37.8 \\
\hline 10 & 32.1 & 1.0 & & 2.1 & & 2.2 & 37.8 \\
\hline 11 & 22.3 & 2.1 & $(36.2)^{b}$ & 0.8 & & 2.1 & $(37.1)^{b}$ \\
\hline 12 & 51.0 & 2.1 & $(36.2)^{b}$ & 0.7 & & 1.8 & 31.5 \\
\hline 13 & 30.4 & 1.0 & & 1.9 & & 2.2 & 31.5 \\
\hline 14 & 116.8 & 1.0 & & 0.9 & & 1.1 & - \\
\hline 15 & 126.6 & & & & & & \\
\hline 16 & 131.9 & 1.1 & & 0.8 & & 1.1 & - \\
\hline 17 & 129.6 & 0.9 & & 0.8 & & 1.0 & - \\
\hline 18 & 120.1 & 0.9 & & 0.8 & & 1.0 & - \\
\hline 19 & 110.9 & 1.0 & & 0.9 & & 1.1 & - \\
\hline 20 & 141.5 & 0.9 & & 0.8 & & 1.2 & - \\
\hline 21 & 17.0 & 2.2 & & 0.9 & & 2.5 & 35.4 \\
\hline 22 & 23.4 & 2.3 & & 0.7 & & 2.4 & 35.0 \\
\hline 23 & 24.8 & 2.3 & & 0.7 & & 2.4 & 34.2 \\
\hline 24 & 22.9 & 2.3 & & 0.9 & & 2.3 & $(36.0)^{b}$ \\
\hline 25 & 29.7 & 1.0 & & 2.2 & & 2.5 & 41.3 \\
\hline 26 & 126.6 & 2.2 & & 0.6 & & 2.0 & 41.2 \\
\hline 27 & 131.2 & 1.0 & & 2.1 & & 2.3 & 41.5 \\
\hline 28 & 18.3 & 2.2 & & 0.8 & & 2.2 & $(47.2)^{b}$ \\
\hline 29 & 25.8 & 2.5 & & 0.8 & & 3.1 & 41.6 \\
\hline 30 & 71.6 & 0.9 & & 2.0 & & 2.3 & 50.1 \\
\hline 31 & 69.9 & 2.6 & & 0.9 & & 2.4 & 50.0 \\
\hline 32 & 60.2 & 1.0 & & 1.7 & & 2.0 & $(40.0)^{b}$ \\
\hline 33 & 25.1 & 2.3 & & 0.8 & & 3.2 & 43.6 \\
\hline 34 & 19.7 & 2.2 & & 0.8 & & 2.6 & 43.7 \\
\hline
\end{tabular}

a Values indicate $\mathrm{X}$-fold enrichment levels as compared with natural abundance.

${ }^{b}$ Values in parentheses result from multiple labeling.

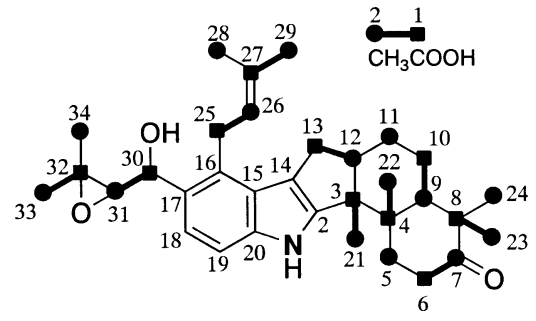

Fig. 2 Incorporation patterns of $\left[{ }^{13}\right.$ Clacetate into sespendole. was inoculated into a 500-ml Erlenmeyer flask with $100 \mathrm{ml}$ of seed medium containing $2.0 \%$ glucose, $0.2 \%$ yeast extract (Oriental Yeast Co.), $0.05 \% \mathrm{MgSO}_{4} \cdot 7 \mathrm{H}_{2} \mathrm{O}, 0.5 \%$ Polypepton (Pharmaceutical CO., LTD.), $0.1 \% \mathrm{KH}_{2} \mathrm{PO}_{4}$ and $0.1 \%$ agar, adjusted to $\mathrm{pH} 6.0$ prior to sterilization and shaken with a rotary shaker at $210 \mathrm{rpm}$ at $27^{\circ} \mathrm{C}$ for 4 days. The main culture was initiated by transferring $1 \mathrm{ml}$ of the seed culture into ten 500-ml Erlenmeyer flasks with $100 \mathrm{ml}$ of production medium containing $2.0 \%$ sucrose, $1.0 \%$ 


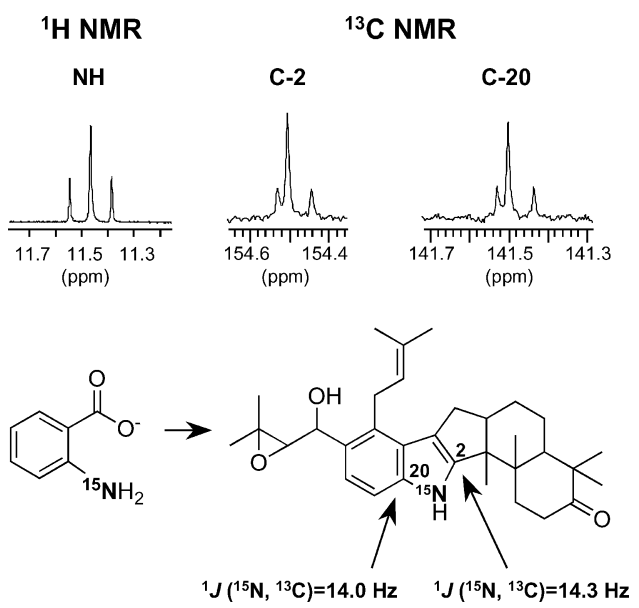

Fig. 3 Incorporation of $\left[{ }^{15} \mathrm{~N}\right]$ anthranilate into sespendole.

Analysis of the NMR spectra of sespendole produced in the presence of $\left[{ }^{15} \mathrm{~N}\right]$ anthranilate showed the $\mathrm{NH}$ proton and two carbon signals with distinct satellites resulting from ${ }^{1} \mathrm{H}-{ }^{15} \mathrm{~N}$ and ${ }^{13} \mathrm{C}-{ }^{15} \mathrm{~N}$ coupling.

glucose, $0.5 \%$ corn steep powder (Iwaki Co., Ltd.), $0.5 \%$ meat extract (Kyokuto Pharmaceutical Co. Ltd.), $0.1 \% \mathrm{KH}_{2} \mathrm{PO}_{4}, 0.05 \% \mathrm{MgSO}_{4} \cdot 7 \mathrm{H}_{2} \mathrm{O}, 0.3 \% \mathrm{CaCO}_{3}$ and $0.15 \%$ agar, adjusted to $\mathrm{pH} 6.0$ prior to sterilization, and fermentation was carried out at $27^{\circ} \mathrm{C}$ with agitation at $210 \mathrm{rpm}$.

\section{Isolation Procedures}

After 4 days of fermentation, the culture broth $(100 \mathrm{ml})$ was centrifuged to obtain the mycelium, which was treated with acetone. After concentration by removing acetone, the aqueous solution was extracted with ethyl acetate $(30 \mathrm{ml})$. The organic layer was dried over $\mathrm{Na}_{2} \mathrm{SO}_{4}$ and concentrated under reduced pressure to give a brown oil. The oil was washed with hexane and the residue containing 1 was purified by HPLC under the following conditions: column, Pegasil ODS (Sensyu Scientific Co., Ltd., i.d. 20× $250 \mathrm{~mm}$ ); mobile phase, $60 \%$ aq $\mathrm{CH}_{3} \mathrm{CN}$; flow rate, $8 \mathrm{ml} /$ minute; detection, UV $240 \mathrm{~nm}$. Compound 1 was eluted as a peak with a retention time of 16 minutes. The peak was collected and the fractions were concentrated to dryness to give pure $\mathbf{1}$ as a colorless amorphous solid.

\section{Biosynthetic ${ }^{13} \mathrm{C}$ and ${ }^{15} \mathrm{~N}$-Labeling of Sespendole}

Biosynthetically ${ }^{13} \mathrm{C}$-labeled and ${ }^{15} \mathrm{~N}$-labeled $\mathbf{1}$ were prepared by adding a labeled precursor $(0.1 \mathrm{mg} / \mathrm{ml}$ of sodium [1$\left.{ }^{13} \mathrm{C}\right],\left[2-{ }^{13} \mathrm{C}\right]$ or $\left[1,2-{ }^{13} \mathrm{C}\right]$ acetate or $\left[{ }^{15} \mathrm{~N}\right]$ anthranilic acid solution) to the culture $(100 \mathrm{ml})$ during cultivation for 40 hours. Labeled 1 was purified as described above.
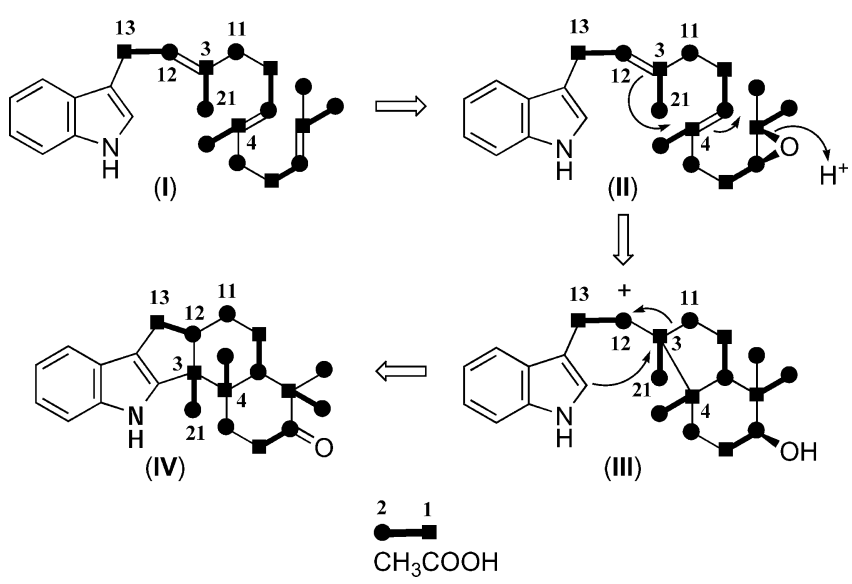

Fig. 4 A possible mechanism of cyclization and rearrangement to form the indolosesquiterpene core structure in sespendole.

\section{Results and Discussion}

$\left[{ }^{13} \mathrm{C}\right]$ Acetate Incorporation

Metabolism of $\left[1-{ }^{13} \mathrm{C}\right]$ acetate or $\left[2-{ }^{13} \mathrm{C}\right]$ acetate through the mevalonic acid pathway should lead to ${ }^{13} \mathrm{C}$ incorporation at the 1 and 3 or the 2, 4 and 5 positions of isopentenyl pyrophosphate (IPP), respectively. $\left[{ }^{13} \mathrm{C}\right]$ Sespendole was prepared biosynthetically using sodium $\left[{ }^{13} \mathrm{C}\right]$ acetate. All of the ${ }^{13} \mathrm{C}$ NMR data of the ${ }^{13} \mathrm{C}$-enriched $\mathbf{1}$ are summarized in Table 1. From the sodium $\left[1-{ }^{13} \mathrm{C}\right]-$ and $\left[2-{ }^{13} \mathrm{C}\right]$ acetate incorporation experiments, 10 carbons $(\mathrm{C} 3, \mathrm{C} 4, \mathrm{C} 6, \mathrm{C} 8$, $\mathrm{C} 10, \mathrm{C} 13, \mathrm{C} 25, \mathrm{C} 27, \mathrm{C} 30$ and $\mathrm{C} 32)$ and 15 carbons (C5, $\mathrm{C} 7, \mathrm{C} 9, \mathrm{C} 11, \mathrm{C} 12, \mathrm{C} 21, \mathrm{C} 22, \mathrm{C} 23, \mathrm{C} 24, \mathrm{C} 26, \mathrm{C} 28, \mathrm{C} 29$, $\mathrm{C} 31, \mathrm{C} 33$ and $\mathrm{C} 34)$ were enriched in $\left[{ }^{13} \mathrm{C}\right]$, as illustrated in Fig. 2. Analysis of ${ }^{13} \mathrm{C}-{ }^{13} \mathrm{C}$ couplings of $\mathbf{1}$ prepared from the sodium $\left[1,2-{ }^{13} \mathrm{C}\right]$ acetate incorporation experiments indicated 10 pairs. These data indicated that the two isopentenyl moieties attached to the indole benzene ring are derived from IPP and that the aliphatic $\mathrm{C}_{15}$ unit connected to the 2,14-positions of the indole ring appears to be derived from a farnesyl group, although the labeling pattern of the five carbons $\mathrm{C} 3, \mathrm{C} 11, \mathrm{C} 12, \mathrm{C} 13$ and $\mathrm{C} 21$ is unusual.

\section{$\left[{ }^{15} \mathrm{~N}\right]$ Anthranilic Acid and $\left[{ }^{13} \mathrm{C}\right]$ Tryptophan Incorporation}

The biosynthetic origin of the indole moiety was examined. An attempt to incorporate $\left[2-{ }^{13} \mathrm{C}\right]$ tryptophan into $\mathbf{1}$ was unsuccessful; no ${ }^{13} \mathrm{C}$ enrichment of any carbon in $\mathbf{1}$ was observed. This result was unexpected in view of the reported incorporation of tryptophan into the indoloditerpene penitrem $\mathrm{A}[4,5]$. Next, the incorporation of $\left[{ }^{15} \mathrm{~N}\right]$ anthranilic acid, a precursor of tryptophan 


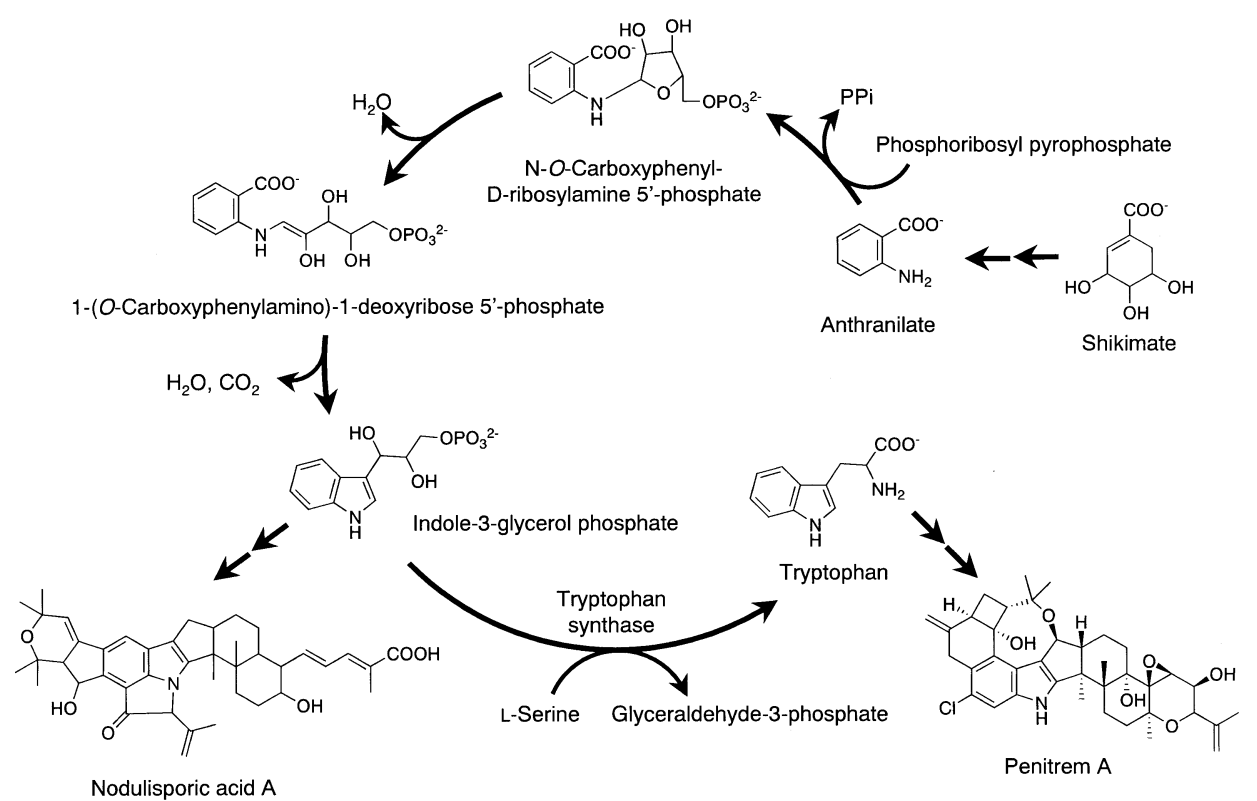

Fig. 5 Tryptophan biosynthesis and biosynthetic pathway producing penitrem A and nodulisporic acid A having indoloditerpene structures.

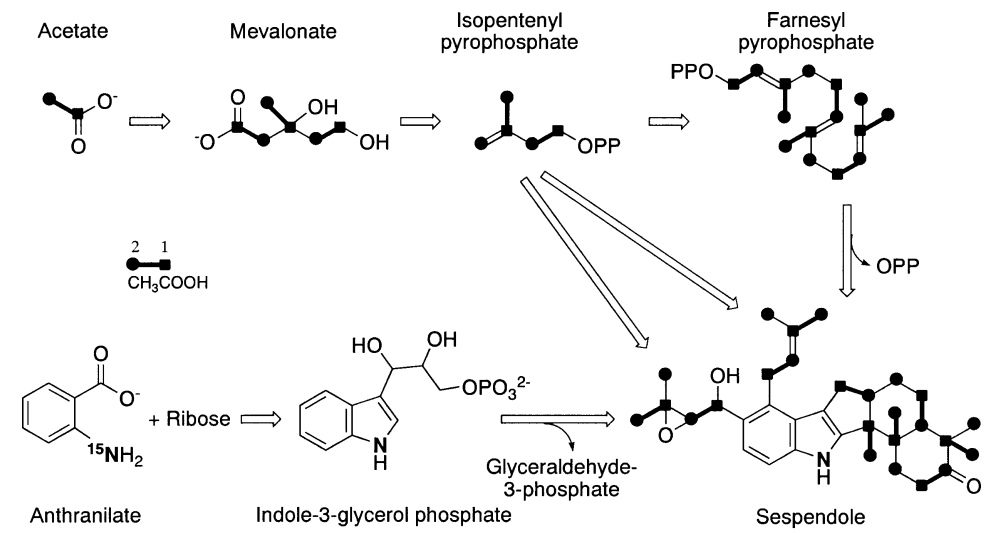

Fig. 6 Summary of the proposed biosynthetic scheme for $\mathbf{1}$.

biosynthesis, was tested. In the ${ }^{13} \mathrm{C}$ NMR spectrum taken in $\mathrm{CD}_{3} \mathrm{OD}$ of $\mathbf{1}$ obtained from the $\left[{ }^{15} \mathrm{~N}\right]$ anthranilic acid feeding experiment, distinct satellite signals due to the ${ }^{13} \mathrm{C}-{ }^{15} \mathrm{~N}$ coupling were observed at $\mathrm{C} 2(\delta 154.6 \mathrm{ppm})$ and C20 ( $\delta 141.5 \mathrm{ppm})$ (Fig. 3). The respective values of the satellite couplings were 14.3 and $14.0 \mathrm{~Hz}$, which were in agreement with the expected range of within $15 \mathrm{~Hz}$ [7]. Furthermore, in the ${ }^{1} \mathrm{H}$ NMR spectrum taken in $\mathrm{C}_{5} \mathrm{D}_{5} \mathrm{~N}$, a distinct satellite due to ${ }^{1} \mathrm{H}-{ }^{15} \mathrm{~N}$ coupling was also observed for the NH proton signal ( $\delta 11.46 \mathrm{ppm})$ (Fig. 3). Thus, it was demonstrated that anthranilic acid is incorporated in the indole moiety of $\mathbf{1}$.

\section{Biosynthesis of Sespendole}

Labeling of 1 with sodium $\left[{ }^{13} \mathrm{C}\right]$ acetate (Fig. 2) indicated that the sesquiterpene moiety and the two side chains of $\mathbf{1}$ are biosynthesized via the mevalonate pathway. However, the labeling pattern of the five carbons (C-3, C-11, C-12, C13 and C-21) is unusual, suggesting that a rearrangement should occur during the condensation and cyclization of farnesyl pyrophosphate (FPP) with the indole moiety. A possible process for the cyclization and rearrangement is shown in Fig. 4; 2-(10,11-epoxyfarnesy)-indole (II) is cyclized to form an intermediate (III), which is rearranged along with 1,2 migration of the $\mathrm{C} 3-\mathrm{C} 11$ bond to yield an indolosesquiterpene skeleton (IV). This rearrangement was 
supported by the observation that the two prominent ${ }^{13} \mathrm{C}-{ }^{13} \mathrm{C}$ couplings of 1 prepared from sodium $\left[1-{ }^{13} \mathrm{C}\right]$ - and $\left[2-{ }^{13} \mathrm{C}\right]$ acetate were $40.5 \mathrm{~Hz}$ between $\mathrm{C}-3$ and $\mathrm{C}-4$, and $36.2 \mathrm{~Hz}$ between $\mathrm{C}-11$ and $\mathrm{C}-12$, respectively. Similar rearrangements were reported in studies on the biosynthesis of the indoloditerpene skeleton in penitrem $\mathrm{A}[4,5]$ and nodulisporic acid A [6].

Regarding the origin of fungal indole moieties, two biosynthetic pathways have been reported, as illustrated in Fig. 5. For most indoloditerpenes, such as penitrem A [4, 5], 3-hydroxy-3-methylbutenyl paspalinine [8] and paxilline [8], tryptophan is used as a precursor for the indole moiety, while indole-3-glycerol phosphate, a precursor of tryptophan biosynthesis, is directly incorporated into nodulisporic acid A [6]. In studies of sespendole, anthranilic acid was found to be incorporated into the molecule but tryptophan was not. These results indicated that the indole moiety of sespendole is biosynthesized from anthranilic acid via indole-3-glycerol. Thus, we demonstrated the biosynthetic origin of sespendole having the indolosesquiterpene core.

The biosynthetic scheme producing $\mathbf{1}$ is summarized in Fig. 6. FPP derived from the classic mevalonic acid pathway condenses with indole-3-glycerol phosphate derived from anthranilic acid and ribose, and then cyclization occurs along with rearrangement. Finally, two dimethylallyl pyrophosphate are incorporated into $\mathrm{C}-16$ and $\mathrm{C}-17$ to form 1.

Acknowledgments We express our thanks to Dr. S. Iwasaki, The Kitasato Institute, for useful comments and discussion. This work was supported by a grant for Scientific Research on Priority Areas (No. 16073215) and a grant from the 21st Century COE
Program from the Ministry of Education, Culture, Sports, Science and Technology, Japan and a grant from the Hoh-ansha Foundation, Japan.

\section{References}

1. Uchida R, Kim YP, Namatame I, Tomoda H, Ōmura S. Sespendole, a new inhibitor of lipid droplet synthesis in macrophages, produced by Pseudobotrytis terrestris FKA25. J Antibiot 52: 93-97 (2006)

2. Uchida R, Kim YP, Nagamitsu T, Tomoda H, Ōmura S. Structure elucidation of fungal sespendole, an inhibitor of lipid droplet synthesis in macrophages. J Antibiot, in press

3. Yamaguchi Y, Masuma R, Kim YP, Uchida R, Tomoda H, Ömura S. Taxonomy and secondary metabolites of Pseudobotrytis sp. FKA-25. Mycoscience 45: 9-16 (2004)

4. de Jesus AE, Hull WE, Steyn PS, van Heerden FR, Vleggaar R, Wessels PL. High-field carbon-13 NMR evidence for the formation of acetate-1,2- ${ }^{13} \mathrm{C}_{2}$ from acetate- $2-{ }^{13} \mathrm{C}$ during the biosynthesis of penitrem A by Penicillium crustosum. J Chem Soci Chem Comm 15: 837-838 (1982)

5. de Jesus AE, Gorst-Allman CP, Steyn PS, van Heerden FR, Vleggaar R, Wessels PL, Hull WE. Tremorgenic mycotoxins from Penicillium crustosum. Biosynthesis of penitrem A. J Chem Soc Perkin Trans 1: 1863-1968 (1983)

6. Byrne KM, Smith SK, Ondeyka JG. Biosynthesis of nodulispolic acid A: precursor studies. J Am Chem Soc 124: 7055-7060 (2002)

7. Kalinowski HO, Berger S, Braun S. Carbon-13 NMR spectroscopy. pp. 568-576, John Wiley \& Sons Ltd, New York (1988)

8. Laws I, Mantle PG. Experimental constraints in the study of the biosynthesis of indole alkaloids in fungi. J Gen Microbiol 135: 2679-2692 (1989) 